\title{
Manifestation Culture of Banjar Ethnic In The Lyrics Of The Song Uma Abah (Anthropolinguistic Approach)
}

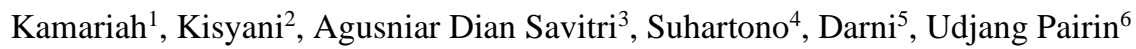 \\ \{kamariah.19015@mhs.unesa.ac.id\} \\ Course Study Language and Literature Education, Postgraduate Universitas Negeri Surabaya
}

\begin{abstract}
The Banjar ethnic group is an ethnic group that inhabits the South Kalimantan region, Indonesia. The Banjar ethnic group has a variety of local wisdom, one of which is folk songs. The Banjar folk song contains cultural manifestations that reflect the Banjar ethnic identity. This identity can be seen from the perspective of the life and work ethic of the Banjar ethnic group owned by the community. This study uses an anthropolinguistic approach with a qualitative descriptive research method. The data source in this study was the Banjar song lyrics with the title, Uma Abah. The song is a creation of H. Anang Ardiansyah. The results showed that the Banjar ethnic group has a view of life and a work ethic that they usually apply in their daily life. The Banjar ethnic view of life is (1) belief in God, (2) belief in customs, and (3) a view of life in the form of reflection. Meanwhile, the work ethic of the Banjar community is in the form of (1) hard work, (2) being responsible, (3) diligent, and diligent.
\end{abstract}

Keywords: cultural manifestations, views of life, work ethic, anthropolinguistic

\section{Introduction}

Banjar songs are songs sung in the Banjar language as the medium of delivery [1]. Tribowo concluded that the Banjar song has three distinctive features, namely, 1) have major harmonies in some parts of the song, 2) Banjar songs are created from murmurs, and 3) Banjar singers have a unique cengkok which makes them different from other folk songs [2]. One of the famous Banjar songwriters is H. Anang Ardiansyah, he is a Banjar song maestro. According to Putra, $\mathrm{H}$. Anang Ardiansyah is a Banjar songwriter who is full of sensitivity in composing songs. All the songs he composed can bring anyone who is listening in to the world of imagination that is presented in the song. Also, the lyrics of the songs that were created are full of life philosophy. Contains moral, ethical, religious messages and embedded in it the Banjar local cultural identity presented in polite Banjar language [3].

Banjar songs contain Banjar language lyrics which are full of cultural values. The Banjar song itself according to $\mathrm{H}$. Anang Ardiansyah in the lyrics of the Banjar song has a characteristic, namely, there are three types of rhymes that have a typical Banjar cultural rhythm. The poem is, rantauan, padahan, and pasisiran. The three rhyme languages have differences due to the origin of the area where the song is developed [4]

Research on the Banjar song has been carried out by several researchers with different forms of study. Some of them will be written in this article. Humaidi researched the cultural values contained in the Banjar song. The results of his research indicate that the Banjar song 
contains cultural values, namely the culture of marriage, livelihood, and traditional games [5]. The difference between the research conducted by Humaidi and this research is that it is seen from the results of the research, Humaidi in his research only describes the cultural values contained in the Banjar song, while this research is more about the manifestation of Banjar culture which is a reflection of the identity of the Banjar ethnic group.

Another research was conducted by Najamudin, in his, research Najamudin analyzed a Banjar song entitled Kambang Goyang by using semiotic studies. The results of his research show that the song lyrics contain Banjar cultural values which are very meaningful, namely regarding the nature of humans themselves and others and the essence of a work, namely a song for the audience [6]. The research conducted by Najamudin is certainly different from this research, the main difference is in the choice of approach or study used. Najamudin's research used a semiotic study, while this research used an anthropolinguistic approach.

Anthropolinguistics According to Siberani, it is a science that studies language from an anthropological and cultural perspective from a linguistic perspective and other aspects of life from a shared perspective [7]. Anthropolinguistics is a combination of linguistic anthropology and anthropological linguistics and is refined with the aim of cultural revitalization [8]. Siberani further explained that anthropolinguistics is a language study that relates the role of language in various cultural activities in human life. This is because the culture is one of the dominant aspects of human life. The anthropolinguistic approach focuses on the process of understanding the intricacies of culture through language studies. The entry point of the anthropolinguistic perspective is a language which is then used to explore a culture and other aspects of human life [9].

Relevant research that uses anthropolinguistics as an approach has been carried out by many researchers, including research conducted by Sinaga et al. Their research aims to find the types and meanings of the Saluh Suh performative verbs of the Simalungun ethnicity. From the results of their research, it was concluded that the Simalungun language is local wisdom and a cultural source that must be preserved [10]. Another research conducted by Lubis [11] focuses on the meaning of speech containing hate speech on Facebook and WhatsApp pages using an anthropolinguistic approach. The results of his research show that the hate speech made by these social media users aims to maintain their position, get sympathy from others, and even income. The similarity of this study with the two previous studies is the use of anthropolinguistics as an approach, while the difference is in the object of research.

Manifestation is a manifestation of something that cannot be seen [12]. This word manifestation has two-word functions, namely as a verb and a noun. In its meaning as a noun, manifestation means turning something into a visible form or giving shape. Whereas in its function as a noun, a manifestation is defined as the embodiment of a statement about feelings or opinions. Manifestation can appear in a culture, where the definition of the culture itself is as human thought, feeling, and action. It can be said that culture as the driving force of humans without human culture is just a meaningless creature [13].

Another opinion about culture is also defined by Geertz, according to his culture is a pattern of meaning that has a conception and is manifested in the form of symbols and is then passed on from generation to generation as a means of communication, preservation, and development of knowledge of life attitudes. Apart from being a means of communication, culture is also a social identity [14]. So, it can be concluded that cultural manifestation means the embodiment of a thought, feeling, and human behaviour that has meaning seen in the form of symbols which are then passed down from generation to generation to become an identity of the user of that culture. 
Based on the facts presented above, it can be concluded that research on the manifestation of Banjar ethnic culture in the lyrics of South Kalimantan regional songs using an anthropolinguistic approach as a study has never been carried out. So that this research is something new and the results of this research will be very useful for the revitalization of Banjar culture and language. Besides, this research will also enrich the treasures of anthropolinguistic studies. The focus of this research is to describe the Banjar ethnic view of life and the Banjar ethnic work ethic.

\section{Research Methods}

The research method used in this research is the descriptive qualitative method. Qualitative descriptive is a method that produces data in the form of words obtained from objects in the form of observable utterances or actions [15]. The approach used in this research is an anthropolinguistic approach. An anthropolinguistic approach is an interdisciplinary approach that can be applied in researching language, culture, and other aspects of humanity [8].

The anthropolinguistic approach has an important role in describing, analysing, and evaluating language, culture, and other aspects that affect humans. The data source in this research is the lyrics of the song Banjar by H. Anang Ardiansyah entitled Uma Abah. The selection of these songs as the object of research is based on the cultural content contained in the lyrics which describes the Banjar ethnic-cultural manifestations in the form of a view of life and work ethic.

\section{Results and Discussion}

The data exposure in this study is divided into an analysis of the cultural manifestations of the Banjar ethnic group in the lyrics of the South Kalimantan regional songs presented in the order of focus of the research, namely the Banjar ethnic view of life and work ethic. The following are the results of the analysis of the two research focuses.

\subsection{Ethnic Views of Life}

View of life is a way of life that is adhered to by groups of society that contains values and reflects self-image because it reflects the ideals and aspirations of the individual (Koentjaraningrat 2009) [16] The Banjar ethnic view of life in the lyrics of a South Kalimantan regional song includes (1) belief in God, (2) belief in customs, (3) reflection. A detailed analysis of the ethnic view of life is presented as follows.

\section{Belief in God}

Believing in God is a form of a man's faith in God. The form of belief in God is to believe in his existence, carry out his commands, and pray and surrender to God. There are seven data found in the lyrics of the Banjar song entitled Uma Abah which shows the Banjar ethnic manifestations of belief in God, the following is the analysis.

Mencariakan rajakinya (looking for sustenance for him)

Seeking fortune is a form of belief from a servant to his Lord. In this song, it is mentioned that parents, namely mothers and fathers, go to work to find sustenance for their children. Sentence mancariakan razakinya (looking for sustenance for him) is a word that indicates that 
the parent goes to work and hopes to get sustenance for his child. Why is it intended for children because as it is believed that provision for children has been arranged by God so that humans who have the intention to seek sustenance for their children will be facilitated in obtaining it. The Banjar people believe in this so that for the Banjar people, children themselves are a provision, so trying to be for children is certainly not a burden but a form of worship to God.

Kugantiakan (I'll replace it)

Lawan sagala pahalaku (With all my nails)

Kugantiakan (I'll replace it)

Lawan sagala amalku (Fight all my charities)

The two-song lyrics above refer to belief in God where all good deeds that have high value and will be rewarded by Allah. All these deeds and rewards will later become a judgment from God about how good and bad that person is while he is alive and will be replaced by heaven when that person dies. So merit and charity are the fruit of belief in God and to get it one must be diligent in doing good deeds. The Banjar ethnic group strongly believes in the reward given by God to them and they also believe that this charity will be carried when they die and a child can send a prayer to his parents who have died and the prayer will later become additional charity and expense for the parent.

\section{Ya Allah, Ya Rabbi}

$\mathrm{Ya}$ Allah Ya Rabbi is a form of glorification in the name of God, the opening word in a prayer, a form of request, and a call for God to hear and answer the prayer offered. The exclamation sentence describes the identity of the Banjar people who are religious and the majority of the population is Muslim.

Kucium batis uma (I kissed mother's feet)

The manifestation of the lyrics kucium batis uma depicting belief in God based on the hadith of the Prophet Muhammad that heaven is in the foot of the mother so that worship and repayment of a mother's love is a commendable act and a manifestation of belief in God. The Banjar people, who are predominantly Muslim in society, certainly know about the prophet's hadith and will live it as a form of belief in the pillars of faith.

Ampuniakan dosa uma wan abah ku (Forgive the sins of my mother and father)

Sentence ampuniakan dosa uma wan abah ku repeated twice and at the end of the song is also repeated, it illustrates the evidence of sincere prayer to God. Believing in God depicted here is believing that the prayer of a child who acts piously and has faith in Allah with a sincere heart will be heard by Allah.

Allahumma Allah Robbigfirli wali wali dayya

Allahumma Allah Robbigfirli wali wali dayya is a form of prayer for both parents which is the belief of Muslims that routinely praying this prayer either at the end of the prayer or at other mustahabb times will add the reward to the parents whether the parent is alive or dead.

\section{Belief in Customs}

Belief in customs is considered as an ideology that has been adapted to the cultural norms that apply to ethnicity and even the State. On the lyrics of the Banjar song Uma Abah, three lines of lyrics were found which manifested a view of life in the form of belief in customs for the Banjar ethnic group.

Kucium batis uma nang menyayangi (I kissed the feet of the loving mother)

The lyrics of the song above are a form of traditional beliefs of the Banjar people where the Banjar people show their love for their parents by doing basujud (prostration) on the foot. This prostration procession is also carried out to ask forgiveness for all mistakes and ask for 
blessings before doing anything. It is believed that if a child performs this ritual before he carries out a job, his intention will be granted by God thanks to the blessing of the parent.

Kucium tangan abah nang malindungi (I kissed your protective hand)

Kissing hands is a habit of the Banjar people when showing respect to parents, respected people such as teachers or superiors, and to people who are older and older. The habit of kissing the hands of a respected person is a teaching of ethics and ethics which the Banjar ethnic group teaches from generation to generation. Besides kissing the hands, it is also one of the Banjar traditional bridal rituals. This ritual is given a name basujud. Procession basujud In the traditional Banjar bridal ritual, it is carried out to ask for forgiveness for all annoyance and to ask for blessings. The bride and groom sit prostrate in front of the parents while looking down and kissing their hands, the parents then hold the bride's shoulders in approval of the marriage and give prayers of blessing.

Uma Ratu ai.... Abah Raja ai (The mother queen,.... the king's father)

The two pieces of the song lyrics above illustrate a form of respect for parents according to Banjar culture. Queen and King here do not mean the leader of a kingdom but the words Queen and King are interpreted as a form of adoration to both parents, the highest form of a child's devotion. Children will be willing to do anything for the happiness of their parents and as a form of repayment for all the sacrifices, their parents make and raise.

\section{Life Reflection}

Meditation is a view of life whose relative truth measure is due to the influence of individual traits and beliefs from self-perception. There are two lyrics in the song Uma Abah which contain manifestations about the life reflections of the Banjar ethnic group.

Uma.... Mun bulih sakit uma kugantiakan lawan segala pahalaku

(Mother ... If I may get sick, I replace it with all my prizes)

The manifestation of the song lyrics above is a view of life in the form of reflections on all of her mother's struggles in caring for and raising herself but she has not been able to reply to it so if possible, she asks God to lift the pain and replace it with her reward, namely diligently worshiping so that the mother doesn't feel it. sick again due to looking for sustenance to live it. Here is described the personality of the Banjar children who are very devoted to their parents, even though they cannot work to help their parents because they are still small, the Banjar children will always pray for the health of their parents and they are willing to share anything to lift the pain.

Abah... Mun bulih paluh abah kugantiakan lawan segala amalku

(Father ... I can replace my sweat with all my deeds)

The lyrics of the song above contain a child's life reflection on the struggle of his father who is willing to be bathed in sweat to find sustenance for his children so that the child muses and wants to replace all his father's fatigue and sweat with his reward. So that the father does not need to feel tired anymore and bathed in sweat because it has been replaced by the child's charity. Banjar children are taught from childhood to always pray for their parents as a form of devotion to their parents.

\section{Work ethic}

Work ethic can be interpreted as an attitude, character, personality, and customs that are owned by individuals and ethnic groups [17]. Work ethic consists of several aspects, namely, hard work, discipline, honesty, responsibility, diligence and diligence, and being able to use time appropriately (Husni, 2014) [18]. The work ethic found in the lyrics of Banajr's song Uma $A b a h$ is hard work, responsible, diligent, and diligent. Here's the analysis. 
Mangilik Nanang, galuh

caramin matanya

Uma batulak

mancariakan razakinya

work, responsibility, diligence, and diligence. A mother does not care about a very hot day and the pain of having to carry her child while working, the mother still goes to work for her responsibility to her beloved children. It can be seen here that the Banjar people are no exception, a woman has high morale, they are diligent in looking for fortune and diligent in working.
Abah malunta
Father fishing
Baluman tantu pakulihnya
(Not necessarily getting results)
Abah Batulak
(Father Departs)
Mencariakan rajakinya
(Looking for sustenance for his family)

The songs above are manifested by a work ethic, namely working hard, being responsible, diligent, and diligent. A father is willing to get cold all over his body because he is soaked in the water against the current and bad weather. My father worked to provide for his family's needs even though he didn't know whether he would get any results. But with determination and hard work he believed that sustenance would come to him. Hard work was a form of responsibility from the father to seek sustenance to support his family.

\section{Conclusion}

Banjar's ethnic manifestations in the lyrics of Uma Abah's song show that banjar ethnicities have a lively outlook and work ethic that they are used to applying in daily life. Banjar ethnic view of life is, (1) belief in God, (2) belief in customs and (3) the view of life in the form of musings. While the work ethic that banjar people have in the form of, (1) hard work, (2) answerable, (3) diligent and diligent. The view of life and work ethic manifested in the lyrics of Uma Abah song is banjar culture that must be preserved and taught to banjar youth genarasi in addition banjar culture which is the rich culture in Indonesia should be known by all Indonesians.

\section{Acknowledgments}

Thanks are conveyed to the Indonesian Education Fund Management Institute (LPDP RI) for funding this article in full. Hopefully, this article can be useful for the development of science both at home and abroad.

\section{References}

[1] Dinas Kebudayaan Pariwisata Pemuda dan Olahraga Kabupaten Banjar, "Lagu Banjar," Kompasiana, 2013. [Online]. Available: https://disbudpar.banjarkab.go.id/berita-190-lagubanjar.html.

[2] [2] J. A. Tribowo, "Identitas Lagu Banjar," 2016. [Online]. Available: http://www.jefryat.id/2016/04/identitas-lagu-banjar.html .

[3] Z. Putra, "Belajar dari Lagu Banjar," 2016. [Online]. Available: https://www.kompasiana.com/zulfaisalputera/575a0cc895977308065fa3f5/belajar-dari-lagu-banjar. 
[4] S. Mahmudah, "Nilai Budaya dalam Lirik Lagu Banjar Karya Syarifudin MS.," Pelataran Seni J. Pendidik. dan Kaji. Seni, vol. 1, no. 1, pp. 71-80, 2016.

[5] A. Humaidi, "Nilai Budaya dalam Lagu Banjar: Pernikahan, Mata Pencarian, danPermainan Tradisional," Stlistika J. Bahasa, Sastra, dan Pengajarannya, vol. 1, no. 1, pp. 102-113, 2016, doi: 10.33654/sti.v1i1.345.

[6] M. Najamudin, "Nilai Budaya dalam Lirik Lagu 'Kambang Goyang' Karya H. Anang Ardiansyah (Suatu Kajian Semiotik),” Pelataran Seni, vol. 3, no. 1, pp. 39-52, 2018, doi: 10.20527/jps.v3i1.5213.

[7] R. Siberani, AntropolinguistikNo Title. Medan: Poda, 2004.

[8] R. Sibarani, “Anthropolinguistics as Interdiciplinary Approach,” J. Anthr., vol. 1, no. 1, pp. 1-8, 2020.

[9] [9] R. Siberani, "Pendekatan Antropolinguistik Terhadap Kajian Tradisi Lisan," Retorika J. Ilmu Bhs., vol. 1, no. 1, pp. 1-17, 2015.

[10] N. T. Sinaga, R. Sibarani, . P., and B. Agustono, "Performative Verb of Saluh Suh's Incantation in Simalungun Ethnic: An Anthropolinguistic Study,” KnE Soc. Sci., vol. 2019, pp. 876-887, 2019, doi: $10.18502 / \mathrm{kss} . v 3 i 19.4914$.

[11] T. Lubis, "Hate Speech in Facebook and Whatsapp Anthropolinguistic Perspective," in The 1stInternational Interdisciplinary Conference on Linguistic Affairs (IICoLA), 2019, no. October, pp. 1-7, doi: 10.31219/osf.io/8wd3z.

[12] KBBI, "Manifestasi," 2020. [Online]. Available: https://kbbi.kemdikbud.go.id/entri/manifestasi.

[13] G. Hofstede, Cultures and organizations: software of the mind. London: Harper-Collins Publishers, 1994.

[14] C. Geertz, The Interpretation of Cultures. New York: Basic Books Inc., 1973.

[15] J. Moleong, Penelitian Kualitatif. Jakarta: Pustaka Utama, 2010.

[16] Koentjaraningrat, Pengantar Ilmu Antropologi. Jakarta: Rineka Cipta, 2009.

[17] T. A. Darodjat, Pentingnya Budaya Kerja Tinggi \& Kuat Absolute. Bandung: Refika Aditama, 2015.

[18] I. Husni, "Hubungan Etos Kerja Dengan Kinerja Guru Di Smk Negeri 1 Lubuk Sikaping,” J. Bahana Manaj. Pendidik., vol. 2, no. 1, pp. 341-346, 2014. 